\title{
Characteristics of sedimentary environments in brackish marsh soils in relation to organic matter properties (Puck Lagoon, Northern Poland)
}

\author{
"Piotr Hulisz, "*Iwona Krześlak, "**Mirosław T. Karasiewicz
}

\author{
"Department of Soil Science, Faculty of Earth Science, \\ Nicolaus Copernicus University, Lwowska 1, 87-100 Toruń, Poland \\ e-mail: hulisz@umk.pl \\ ** Department of Geomorphology and Palaeogeography of the Quaternary, Faculty of Earth Science, \\ Nicolaus Copernicus University, Lwowska 1, 87-100 Toruń, Poland
}

\begin{abstract}
The research focused on brackish marsh soils located within the coastal zone of Puck Lagoon (the Beka botanical and ornithological nature reserve). They are characterised by the presence of layers rich with allochthonous organic matter, derived from washing out of peat deposits. The objective of the research was to determine sedimentary environments of the soil organic matter based on selected properties. The obtained results indicated that despite similar morphological characteristics, these soils might have developed in slightly different environmental conditions, determined mostly by the Baltic water levels and morphology of the coast. The organic matter of the studied soils was characterised by relatively low aromaticity, which may indicate the ongoing process of decomposition. The presence of both peat-bog, rush and ruderal plants, as well as trees in the species composition of macroremains proved the heterogeneity of sedimentary environments and confirmed the allochthonous origin of organic matter accumulated in the studied brackish marsh soils.
\end{abstract}

Key words: brackish marsh soils, soil organic matter, Baltic Sea, soil genesis, Beka reserve, plant macroremains.

\section{Introduction}

The region of Puck Lagoon includes flat alluvial coasts connected with the Reda and Płutnica ice-marginal valleys. Bottoms of these valleys are filled mostly with peats. In some places, wet meadows and outcrops of Holocene peat and silt deposits occur within the Lagoon shores (Jankowska \& Łęczyński 1993). The presence of such sites obviously favours the development of brackish marsh soils, which are largely affected by seawater. They are among the least known soils in Poland, not distinguished in the currently valid Systematics of Polish Soils (2011). Although there are relatively many studies dealing with the soil cover in the coastal zone of the Lagoon (Pracz 1989; Pracz \& Kwasowski 2005), the soils have not been thoroughly investigated yet.
The preliminary reconnaissance of the brackish marsh soils in the Beka Reserve (the Reda River mouth) revealed their unique nature on the scale of the Polish Baltic coast (Hulisz 2011). They developed from sandy marine sediments, which were deposited mainly during extreme water levels (storms). They are stratified deposits characterised by a large admixture of allochthonous organic matter derived mainly from outcrops of peat deposits washed out by the Baltic waters.

The present paper is a continuation of the aforementioned research. The Authors focused on the soil organic matter, because its properties provides a good indication of the environmental changes (Stuermer \& Payne 1976; Santin et al. 2008), which are also relevant for the genesis of the studied soils. Therefore, the objective of this study was to characterise the sedimentary environments in the 
brackish marsh soils based on the analysis of quantitative and qualitative properties of the organic matter.

Plant macroremain analysis was one of the most important analyses used for this purpose. So far this method has been very seldom applied in the soil science research, but it allows to reconstruct local vegetation, especially in peatlands and lakes (Drzymulska 2003; Kowalewski 2007).

\section{The study area}

Puck Lagoon is a north-western subregion of Gdańsk Bay (Northern Poland), separated from the waters of Puck Bay by partly submerged sandy barrier (Seagull Shallow). Hel Spit constitutes the borderline with the Baltic open waters. According to Kramarska et al. (1995), one can distinguish three series of sediments (of different age and genesis) within the Lagoon area:

- Pleistocene fluvioglacial sands, locally glacial tills and clays,

- Late Glacial and Holocene fluvial, lacustrine and swampy deposits (fine sands, silts with plant remains and peats)

- Holocene sediments of barrier, lagoon and marine origin.

The coastal zone is affected mainly by the level of waters in Puck Lagoon, with the average annual value of $502 \mathrm{~cm}$ for the period of 1951-2000 - the maximum usually occurs in December, the minimum in February. The water salinity is on average ca. 7.3\% (Nowacki 1993). Winds from SW, W and NW directions prevail in the Lagoon. Strong winds (above $10 \mathrm{~m} \cdot \mathrm{s}^{-1}$ ) occur for ca. $60-70$ days a year (Cyberski \& Szefler 1993).

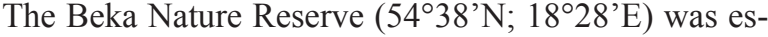
tablished to protect rare communities of halophytes and species of birds. Wet meadows located in this area are flooded during storms by seawaters, i.e. in autumn and winter (Jokiel \& Woźniak 2012). The soil cover of these meadows is mainly dominated by peat soils. Peat deposits are up to $3 \mathrm{~m}$ deep (Błaszkowska et al. 1996). According to Uścinowicz (2006), the calibrated ${ }^{14} \mathrm{C}$ age of these peat deposits can be estimated at 2222-1268 BC (depth of 1.02$1.06 \mathrm{~m} \mathrm{bsl}$ ) and 647-997 AD (depth of 0.40-0.45 m bsl).

The shoreline of Puck Lagoon in the Beka Reserve is characterised by the alternate presence of depositional and abrasive sections. Peats within the depositional sections of the coast are covered by marine sands; in some places their outcrops appear as a result of abrasion. The shores are destroyed at a high rate. This could be evidenced by the fact that in 1957 farm buildings of the former village of Beka were located ca. $100 \mathrm{~m}$ from the shoreline, and at present - just several metres away (Urbański \& Ślimak 2008).

The shores of Puck Lagoon located within the limits of the Beka Reserve are mostly covered by reed beds. Locally narrow sandy beaches may occur with the maximum width of up to a few metres.

\section{Material and methods}

The research was carried out in September 2009 in the coastal zone of Puck Lagoon (the Beka Nature Reserve). Two soil profiles representing the brackish marsh soils were selected (Fig. 1). The first one was located within the beach zone (profile B1, at a distance of $2 \mathrm{~m}$ from the waterline), and the second one - on the beach (storm) ridge (profile $\mathrm{B} 2$, at a distance of $10 \mathrm{~m}$ from the waterline). Additionally, for comparative purposes, a sample from the washed out peat bog shore was collected (B3, depth 0-25 cm).

The following measurements, related to current environmental conditions, were taken in the soil horizons (or layers) during the field works (4 Sept. 2009): redox potential (Eh) and reaction $(\mathrm{pH})$ - by the potentiometric method, moisture content $(\% \mathrm{v} / \mathrm{v})$ and electrical conductivity (EC) - by the TDR (Time-Domain Reflectrometry) method.

In the air-dry soil samples, the organic matter (OM) content was determined by loss on ignition in $550^{\circ} \mathrm{C}$ and $\mathrm{CaCO}_{3}$ content - by the Scheibler method.

In order to determine the chemical structure of carbon compounds in the analysed soil samples, the solid state ${ }^{13} \mathrm{C}$ NMR/CPMAS spectroscopy was applied. The selected solid soil samples were examined in a Bruker MSL-300 spectrometer with the following parameters: frequency for ${ }^{13} \mathrm{C}-75.47 \mathrm{MHz}$ and contact time $-3 \mathrm{~ms}$ (Strzelecka \& Gonet 2009). Structural assignments of ${ }^{13} \mathrm{C}$ chemical shift regions were made according to Kögel-Knabner (1997). The ${ }^{13} \mathrm{C}$ signals were separated into alkyl C (0-45 ppm), N,O-alkyl C (45-60 ppm), carbohydrate C (60-110 ppm), aromatic C (110-160 ppm), carboxyl C (160-190 ppm) and carbonyl C (190-200 ppm). The relative carbon content of different structural groups (expressed in per cent) was determined by integrating the individual chemical shift regions. Aromaticity (Ar) of organic matter was calculated according to the following equation:

$$
\operatorname{Ar}[\%]=(110-160 \mathrm{ppm}):(0-160 \mathrm{ppm}) \times 100
$$

The analysis of plant and animal macroremains was performed in all organic horizons, as well as in horizons enriched with allochthonous organic matter (profiles B1 and B2) and in the sample collected from the eroded peat bog shore (B3). A total of 10 samples (ca. 10-15 ml each) were examined. The analysis of plant macroremains was carried out according to guidelines of the Institute of Botany PAS (Velichkevich \& Zastawniak 2006). The procedure consisted of measuring the volume of the material and boiling it in $10 \% \mathrm{KOH}$ solution in order to remove humic acids. Loose precipitate was washed through a sieve with a mesh diameter of $0.2 \mathrm{~mm}$; this was followed by 


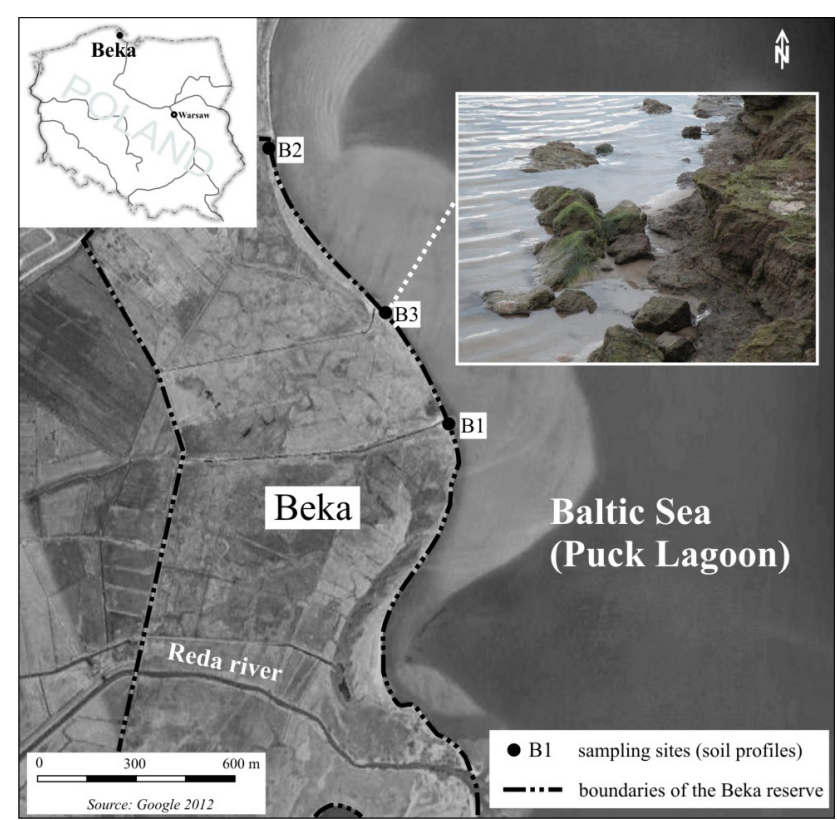

Figure 1. Location of the study area and sampling sites

isolation and identification of macroscopic plant remains under a binocular magnifying glass. The identification was performed based on identification keys and atlases, and the results are presented in the graphic form. Additionally, some animal remains were identified in the analysed soil material (Frey 1964).

Symbols of soil horizons are given after the Guidelines for Soil Description (2006). Due to specific nature of the studied soils, however, it was not possible to indicate the presence of allochthonous organic matter. Therefore, additional symbols were proposed: $\mathrm{Ch}_{(\text {al) }}$ - for mineral horizons and $\mathrm{H}_{(\mathrm{al})}$ - for organic horizons.

\section{Results}

\subsection{Soil properties}

The analysed soils were characterised by distinct and very heterogeneous stratification (Fig. 2). It was possible to distinguish sandy mineral layers (C) with gleyic properties $(\mathrm{Cg})$ at the bottom of profiles. Some of them, referred to as $\mathrm{Ch}_{\text {(al) }}$, were also characterised by the presence of allochthonous organic matter. Furthermore, also levels consisting of macroscopically visible redeposited peat $\mathrm{H}_{(\mathrm{al})}$, muck $(\mathrm{H})$ and organic buried horizons $(\mathrm{Hb})$ were present in the profiles. Based on the aforementioned properties of the soil material, the studied soils were classified as Fluvisols (IUSS Working Group WRB 2007).

The selected properties of the studied soils are presented in Table 1. Due to location within a short distance from the waterline, the analysed soils were constantly affected by shallow groundwater (profiles B1 $-50 \mathrm{~cm}$, profiles B2 $-85 \mathrm{~cm}$ b.s.1.). Additionally, they were also flooded during high levels of the Baltic waters. This undoubtedly contributed to prevalence of periodic anaerobic conditions within profile B1 and sample B3 (Eh 97-290 mV), and permanent anaerobic conditions (Eh $0-19 \mathrm{mV}$ ) at the floor of profile B2. Values of the actual moisture content in the analysed soils, expressed as a percentage by volume, ranged from $7.5 \%$ in surface horizons to $87.9 \%$ in horizons with gleyic properties.

Salinity of the studied soils reflected brackish nature of the waters in Puck Lagoon. Values of the bulk electrical conductivity ranged from $<0.1$ to $2.1 \mathrm{dS} \cdot \mathrm{m}^{-1}$. As evidenced by the data presented in Table 1 , the salt distribution in the profile is not only determined by the constant influence of surface or shallow ground waters. First of all, it was determined by the content of organic matter, which was characterised by large differences: from $0.1-0.5 \%$ in sandy marine sediments, $2.2-9.9 \%$ in sandy sediments enriched with or-
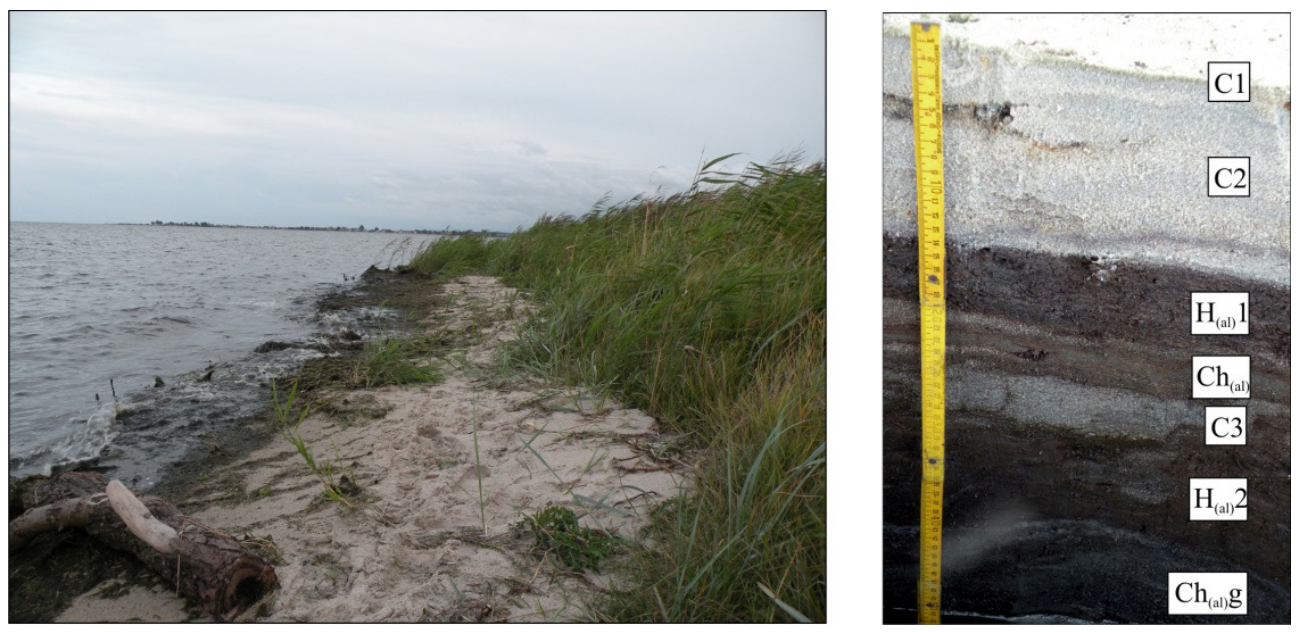

Figure 2. Example of the studied soil (profile B1) 
Table 1. Selected properties of the studied soils

\begin{tabular}{|c|c|c|c|c|c|c|c|}
\hline Horizon & $\begin{array}{l}\text { Depth } \\
{[\mathrm{cm}]}\end{array}$ & $\begin{array}{l}\text { Actual moisture } \\
{[\% \mathrm{v} / \mathrm{v}]}\end{array}$ & $\mathrm{pH}$ & $\begin{array}{l}\mathrm{EC} \\
{\left[\mathrm{dS} \cdot \mathrm{m}^{-1}\right]}\end{array}$ & $\begin{array}{l}\mathrm{Eh} \\
{[\mathrm{mV}]}\end{array}$ & $\begin{array}{l}\mathrm{OM} \\
{[\%]}\end{array}$ & $\begin{array}{l}\text { Soil material } \\
\text { description }\end{array}$ \\
\hline \multicolumn{8}{|c|}{ Profile B1 } \\
\hline $\mathrm{C} 1$ & $0-0.5$ & n.d. & 7.0 & n.d. & n.d. & 0.2 & sandy layer with diatoms and algae \\
\hline $\mathrm{C} 2^{*}$ & $0.5-14$ & 21.3 & 7.1 & 0.7 & 290 & 0.1 & marine loose sand \\
\hline $\mathrm{H}_{(\mathrm{al})} 1$ & $14-19$ & 66.8 & 6.6 & 1.6 & 118 & 14.6 & allochthonous peat \\
\hline $\mathrm{Ch}_{(\mathrm{al})}$ & $19-26$ & 48.7 & 6.9 & 1.2 & 97 & 9.9 & marine loose sand with allochthonous OM \\
\hline $\mathrm{C} 3$ & $26-30$ & 38.7 & 6.9 & 1.0 & 135 & 0.2 & marine loose sand \\
\hline $\mathrm{H}_{(\mathrm{al})} 2$ & $30-44$ & 58.2 & 6.5 & 1.6 & 106 & 17.9 & allochthonous peat \\
\hline $\mathrm{Ch}_{(\mathrm{al})} \mathrm{g}$ & $>44$ & 37.1 & 6.6 & 0.9 & 121 & 2.0 & marine loose sand with allochthonous OM \\
\hline \multicolumn{8}{|c|}{ Profile B2 } \\
\hline $\mathrm{H}$ & $0-5$ & 8.5 & 7.5 & $<0.1$ & 497 & 34.3 & muck \\
\hline $\mathrm{Ch}_{(\mathrm{al)1})}^{* *}$ & $5-11$ & 7.1 & 7.4 & $<0.1$ & 452 & 3.8 & loose marine sand with allochthonous OM \\
\hline $\mathrm{H}_{\text {(al) }} 1$ & $11-12$ & n.d. & 7.7 & n.d. & 410 & 21.4 & organic, allochthonous \\
\hline $\mathrm{C} 1^{* *}$ & $12-16$ & 6.6 & 8.0 & $<0.1$ & 422 & 0.2 & marine loose sand \\
\hline $\mathrm{H}_{(\mathrm{al})} 2$ & $16-17$ & n.d. & 7.8 & n.d. & 394 & 18.5 & organic, allochthonous \\
\hline $\mathrm{C} 2^{* *}$ & $17-27$ & 14.6 & 8.0 & 0.1 & 404 & 0.3 & marine loose sand \\
\hline $\mathrm{Ch}_{(\mathrm{al})} 2$ & $27-28$ & 42.6 & 7.1 & 0.5 & 332 & 8.8 & marine loose sand with allochthonous OM \\
\hline $\mathrm{Ch}_{(\mathrm{al})} 3$ & $28-40$ & 41.4 & 7.3 & 0.7 & 350 & 2.2 & marine loose sand with allochthonous OM \\
\hline $\mathrm{H}_{(\mathrm{al})} 3$ & $40-60$ & 51.2 & 6.5 & 1.0 & 155 & 43.4 & allochthonous peat \\
\hline $\mathrm{Cg}$ & $60-64$ & 31.9 & 6.7 & 0.7 & 19 & 0.5 & marine loose sand \\
\hline $\mathrm{Ch}_{(\mathrm{al})} \mathrm{g}$ & $64-70$ & 54.2 & 6.6 & 1.4 & 6 & 7.0 & marine loose sand with allochthonous peat \\
\hline $\mathrm{Hb} 1$ & $70-78$ & 87.0 & 6.8 & 2.1 & 0 & 53.8 & mud \\
\hline $\mathrm{Hb} 2$ & $78-(90)$ & 87.9 & 6.8 & 2.1 & 4 & 59.1 & low moor peat \\
\hline \multicolumn{8}{|c|}{ Sample B3 } \\
\hline $\mathrm{H}$ & $0-25$ & 66.0 & 6.4 & 2.0 & 122 & 44.3 & low moor peat (storm-damaged seashore) \\
\hline
\end{tabular}

n.d. - not determined $\mathrm{OM}$ - organic matter ${ }^{*} \mathrm{CaCO}_{3}$ content $1.5 \%{ }^{* *} \mathrm{CaCO}_{3}$ content $0.5 \%$

Table 2. CPMAS ${ }^{13} \mathrm{C}$ NMR carbon units of the soil organic matter (\%) in layers (or horizons) of brackish marsh soil (profile B2) in comparison to a peat sample (B3) taken from storm-damaged (abraded) seashore

\begin{tabular}{|c|c|c|c|c|c|c|c|c|}
\hline \multirow{3}{*}{ Sample } & \multirow{3}{*}{$\begin{array}{l}\text { Depth } \\
{[\mathrm{cm}]}\end{array}$} & alkyl & $\begin{array}{l}\text { N,O- } \\
\text { alkyl }\end{array}$ & $\begin{array}{c}\text { carbo- } \\
\text { hydrate }\end{array}$ & aromatic & carboxyl & carbonyl & \multirow{3}{*}{$\begin{array}{c}\mathrm{Ar} \\
{[\%]}\end{array}$} \\
\hline & & \multicolumn{6}{|c|}{ chemical shift [ppm] } & \\
\hline & & $0-45$ & $45-60$ & $60-110$ & $110-160$ & $160-190$ & $190-200$ & \\
\hline \multirow{5}{*}{$\begin{array}{c}\text { Profile } \\
\text { B2 }\end{array}$} & $0-5$ & 20.8 & 14.8 & 37.7 & 16.0 & 9.0 & 1.7 & 17.9 \\
\hline & $16-17$ & 17.5 & 9.8 & 47.1 & 17.5 & 7.4 & 0.7 & 19.0 \\
\hline & $27-28$ & 21.1 & 12.7 & 39.9 & 17.9 & 7.6 & 0.8 & 19.6 \\
\hline & $70-78$ & 31.0 & 8.40 & 30.3 & 17.3 & 11.1 & 1.9 & 19.9 \\
\hline & $78-(90)$ & 22.9 & 11.0 & 31.0 & 24.1 & 9.2 & 1.8 & 27.1 \\
\hline B3 & $0-25$ & 33.2 & 10.3 & 32.2 & 15.0 & 9.0 & 0.3 & 16.5 \\
\hline
\end{tabular}




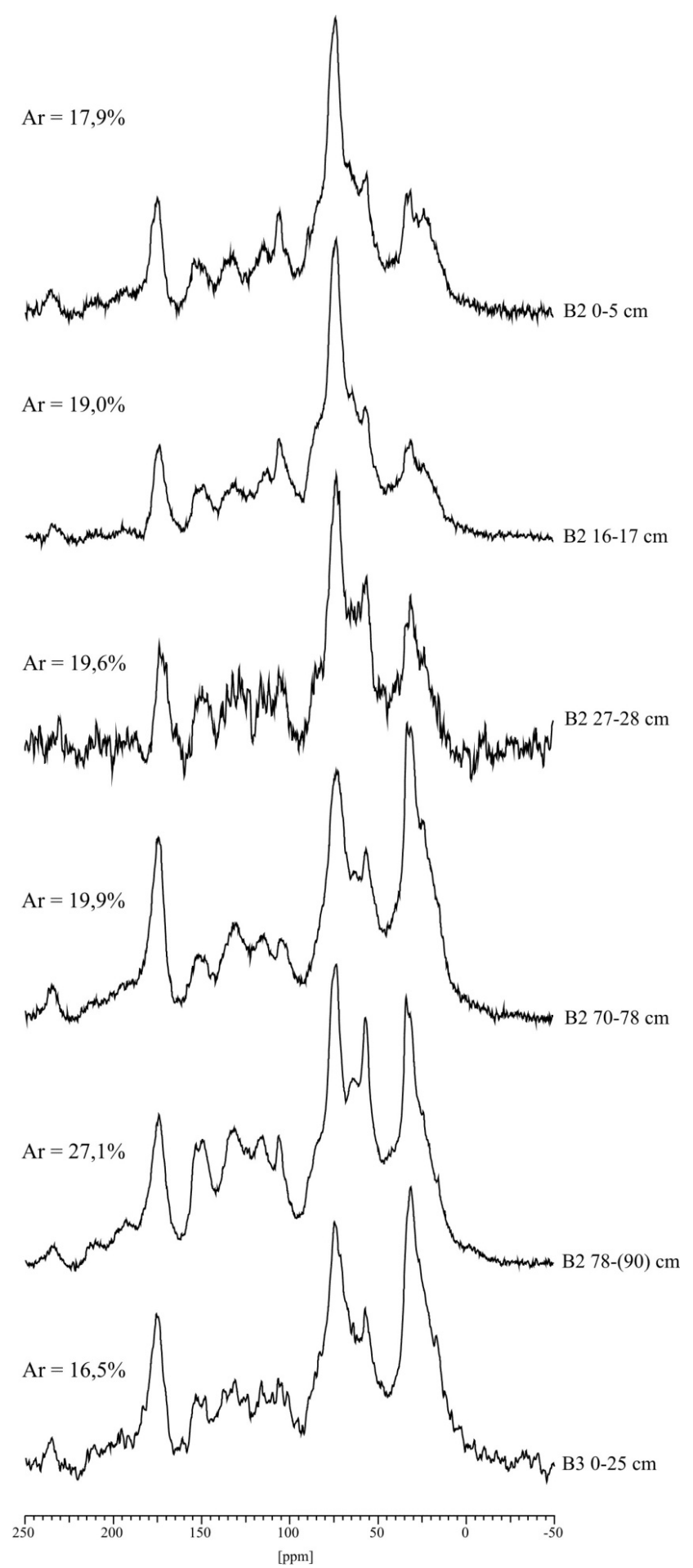

Figure 3. CPMAS ${ }^{13} \boldsymbol{C}$ NMR spectra of the selected soil samples ganic matter, $14.6-43.4 \%$ in layers of allochthonous peat, up to $59.1 \%$ in the buried low moor peat horizon $(\mathrm{Hb} 2)$.

Values of $\mathrm{pH}$ measured in the analysed soils ranged from 6.4 to 8.0 , which is typical of soils affected by neutral salts, mainly $\mathrm{NaCl}$ (Hulisz 2007). Carbonates were found in only three samples with alkaline reaction $\left(\mathrm{CaCO}_{3} 0.5-\right.$ $1.5 \%$, profile B2, Tab. 1), and their presence was associated mainly with remains of malacofauna.

The results of ${ }^{13} \mathrm{C}$ NMR spectra analysis for selected soil samples (B2 and B3) are presented in Table 2 and Fig. 3. It appears from the performed analysis that properties of organic matter from horizons and layers located up to a depth of $78 \mathrm{~cm}$ (Profile B2) and from the abraded peatbog shore (B3) were very similar (Fig. 3). Their spectral bands related to aliphatic humic compounds were noticeably amplified. Thus, the calculated index of aromaticity was relatively low (Ar 17.9-19.9\%). Higher contribution of aromatic carbon compounds $(\mathrm{Ar}=27.1 \%)$ was observed in the low moor peat sample collected from the floor of profile B2 $(78-90 \mathrm{~cm})$.

\subsection{Macroremain composition}

The analysis of macroremains was performed in soil horizons and layers of varying organic matter content: muck, mud and peat (profile B2, sample B3) and mineral enriched with allochthonous organic matter (profiles B1 and B2). The results of identification of macroremain species are presented in Figures 4-6.

Samples collected from the subsurface horizons of profile B1 (depth 14-19 and 30-44 cm) were characterised by considerable dominance of Schoenoplectus tabernaemontani remains (Fig. 4). This plant usually occurs in the form of extensive beds in littoral zones of water bodies and shallow bays with muddy ground (Podbielkowski \& Tomaszewicz 1996). Since the species is tolerant to relatively high salinity it occurs abundantly along the Baltic coast. Zannichellia palustris has similar habitat requirements; seeds of this species were also identified in sediments of profile B1. Other, less abundant remains represented mainly peat-bog and rush (reed beds) habitats. Single achenes of Carex sp. were identified, as well as remains of Menyanthes trifoliata, Eleocharis palustris and Lysimachia vulgaris. Also Characeae oospores, probably halophilous Chara baltica (widespread in this area), were present in large numbers.

Species richness of organic matter in profile B2 was much higher (Fig. 5). As in profile B1, rush and aquatic (macrophyte) vegetation, tolerant to increased salinity, had significant, although irregular contribution, i.e. Characeae, Zannichellia palustris, Ruppia maritima and Schoenoplectus tabernaemontani. Contribution of peat-bog vegetation, mostly Carex sp., was also significant. Further large ecological groups consisted of species characteristic of thickets and wet meadows, including Urtica dioica and Cirsium 


\section{Profile B1}

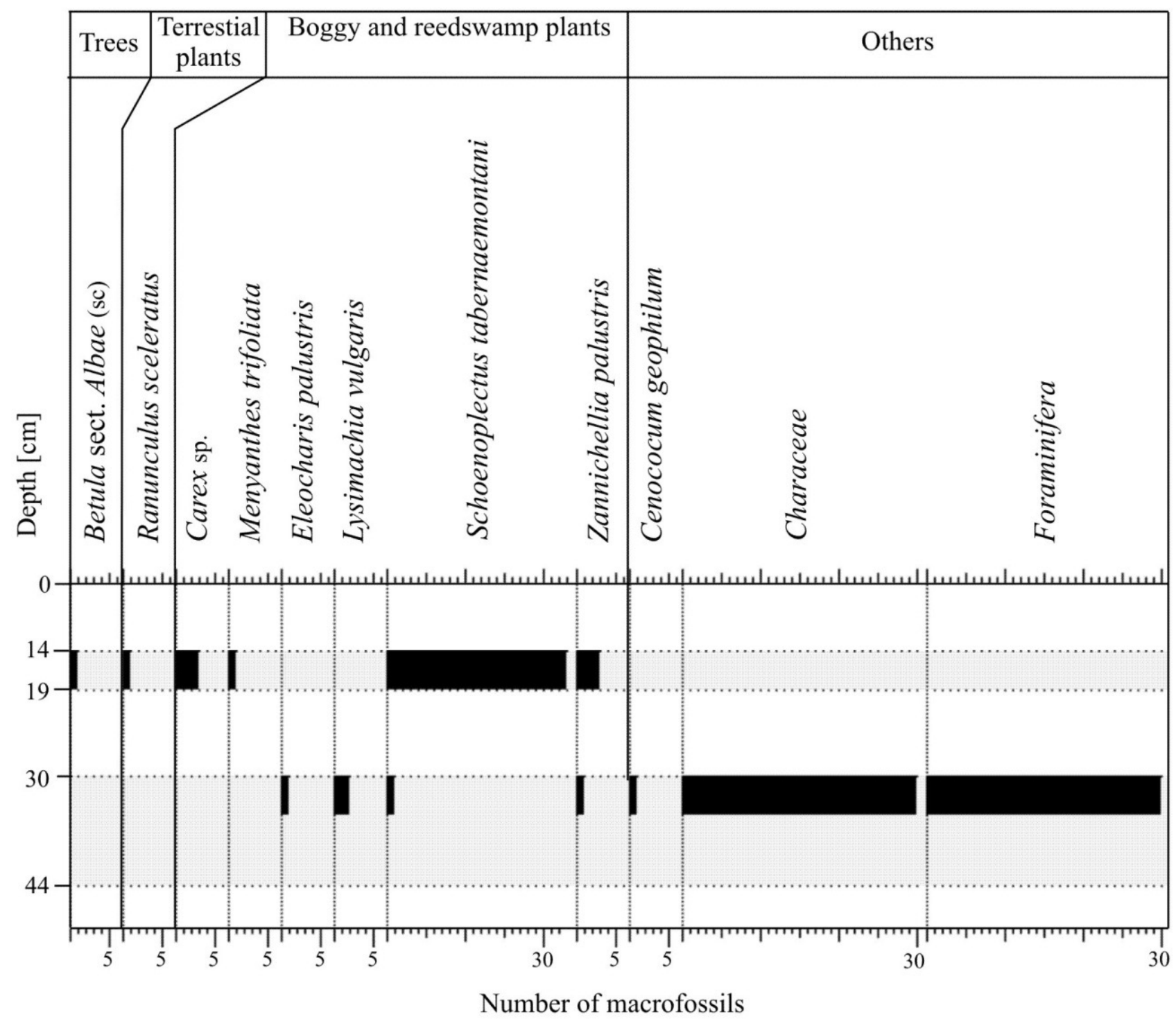

Symbol explanations: (sc)- fruit scale

Figure 4. Macroremain diagram for profile B1

oleraceum. There were no apparent differences in the species composition of macroremains between the horizons enriched with allochthonous organic matter and fossil organic horizons.

Numerous plant remains, not associated with the current habitat and not occurring at the study sites, were identified in samples collected from the top of profile B2. Those were achenes (nuts) and husks of birch trees (Betula sect. Albae). Whereas remains of ruderal plants and weeds were identified in the surface muck horizon $\mathrm{H}(0-5 \mathrm{~cm})$ : Chenopodium sp., Sonchus oleraceus, Galeopsis tetrahit and Lactuca sp. (Fig. 5), which are associated with human settlements (Kornaś 1977). The presence of this shallow horizon certainly proves some stability of land surface (contrary to profile B1).

Only three species were identified in sample B3 collected from the washed out peat-bog shore: Carex sp., Eleocharis palustris and Juncus sp. (Fig. 6). These plants represented habitats of peat bogs and reed beds. The effect of seawater was reflected in the presence of forams (Foraminifera $)$ - marine planktonic species. One can also assume that the identified rush species could be the Baltic rush (Juncus balticus), widespread in Puck Bay (WszałekRożek \& Markowski 2010). 


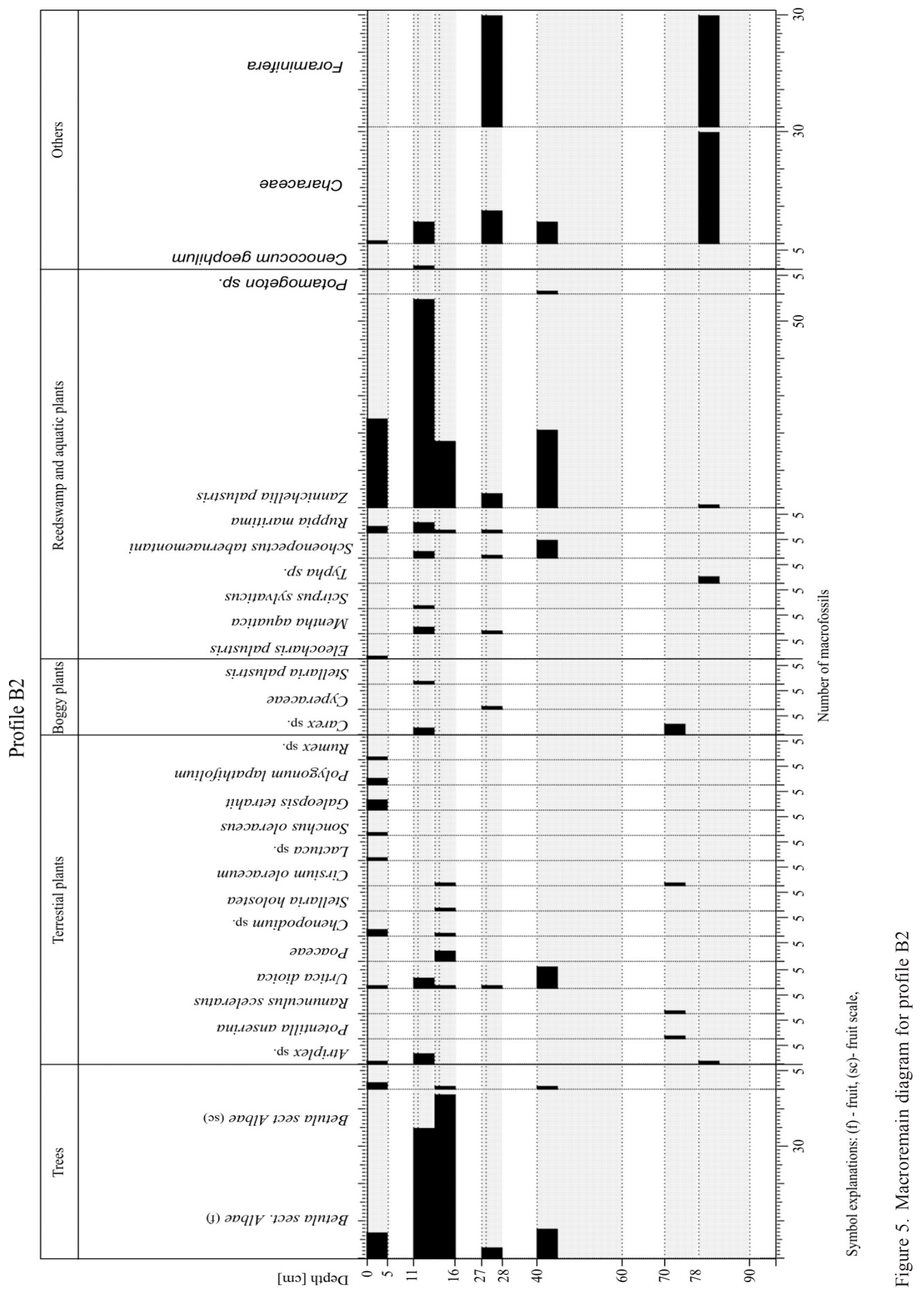


Sample B3

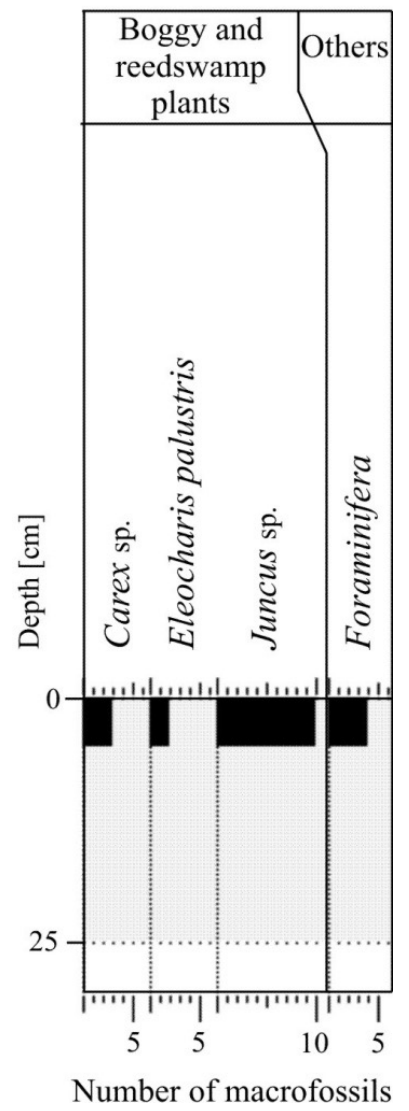

Figure 6. Macroremain diagram for sample B3

\section{Discussion}

The studied area is a small, flat fragment of the Puck Lagoon coast. Alluvial sediments are covered here by paludal-limnic sediments of low resistance to abrasion (Jankowska \& Łęczyński 1993). Due to this specific structure of the Baltic shore in the Beka reserve, the specific type of soils developed. These soils consist of layers and horizons that are heterogeneous in terms of the content of organic matter and carbonates, as well as reaction, salinity and redox conditions (Table 1).

Figure 7 presents a possible development of brackish marsh soils, drawn up based on the obtained results, as well as geomorphological and hydrological literature data (Jankowska \& Łęczyński 1993; Błaszkowska et al. 1996; Jokiel \& Woźniak 2012). At extremely high water levels (storms), the shores of the coastal peat bog are affected by destruction. Fragments of peat are carried away by waves, and then mechanically crumbled (Fig. 7A). The abraded peat bog begins to resemble a microcliff. It seems that resedimentation of organic sediment may proceed in two separate stages covering morphologically different el- ements of the coastal zone, i.e. the beach and the beach ridge at different water levels in the Lagoon.

At low Baltic water levels and within the range of wave motion, the washed out peat is redeposited on the beach alternately with marine sediments (Fig. 7B) - profile B1. During storms, the seawater may overflow the beach ridge. Therefore, in addition to typical sedimentation of marine sediments, such as sands and silts, also redeposition of peat may occur (Fig. 7C). Thus, brackish marsh soils may develop in the close proximity of the shore, but beyond the beach range (profile B2). In both cases, the soil formation is strongly affected by saline waters and by salt concentration in organic matter, which comes from the washed out peat.

The impact of seawater on peat deposits resulted in significant changes in chemical structures of carbon compounds, which was confirmed by the results of ${ }^{13} \boldsymbol{C}$ NMR spectral analysis (Table 2 and Fig. 3). Relatively low aromaticity (below 20\%), typical of marine sediments, is the most important indication of the ongoing transformations (Stuermer \& Payne 1976). This could possibly indicate the ongoing process of organic matter decomposition caused by much better oxygenation of the environment compared to the natural peat deposit where anaerobic conditions prevailed.

High dynamics of the environment in the studied area, related mainly to seawater influence, was evidenced by the presence of buried horizons $\mathrm{Hb} 1$ and $\mathrm{Hb} 2$ in profile $\mathrm{B} 2$, located on the beach ridge. In the case of horizon $\mathrm{Hb} 2$, aromaticity of humic compounds $(27.1 \%)$ could indicate a formation of this horizon in the terrestrial environment. According to Beyer et al. (1996), aromaticity of peats deposited in such conditions may range from 27.9 to $30.6 \%$. Taking into account the morphology of profile B2 and properties of organic matter discussed above, it seems likely that the location of buried horizon $\mathrm{Hb} 2$ could correspond to primary (fossil) land surface, covered by marine sediments.

Based on the analysis of plant and animal macroremains, the authors concluded that their sedimentary environments may have differed within one profile. One should remember, however, that the potential for preservation of macroremains in such a dynamic environment was limited. The process of continuous washing away and redeposition of sediment could have resulted in destruction, loss and decomposition of a large amount of plant and animal remains. Perhaps for this reason, no apparent similarity was observed between the species composition of macroremains identified in buried horizon $\mathrm{Hb} 2$ (profile B2) and in sample B3 (Fig. 5 and 6).

Organic sediments in profiles B1 and B2 were dominated by remains of plants typical of the peat bog-rush zone (often tolerant to increased salinity). At the same time, species representing other (terrestrial and aquatic) habitats were present - Fig. 4 and 5. Such a great heterogeneity of sedimentary environments certainly proved that this mate- 

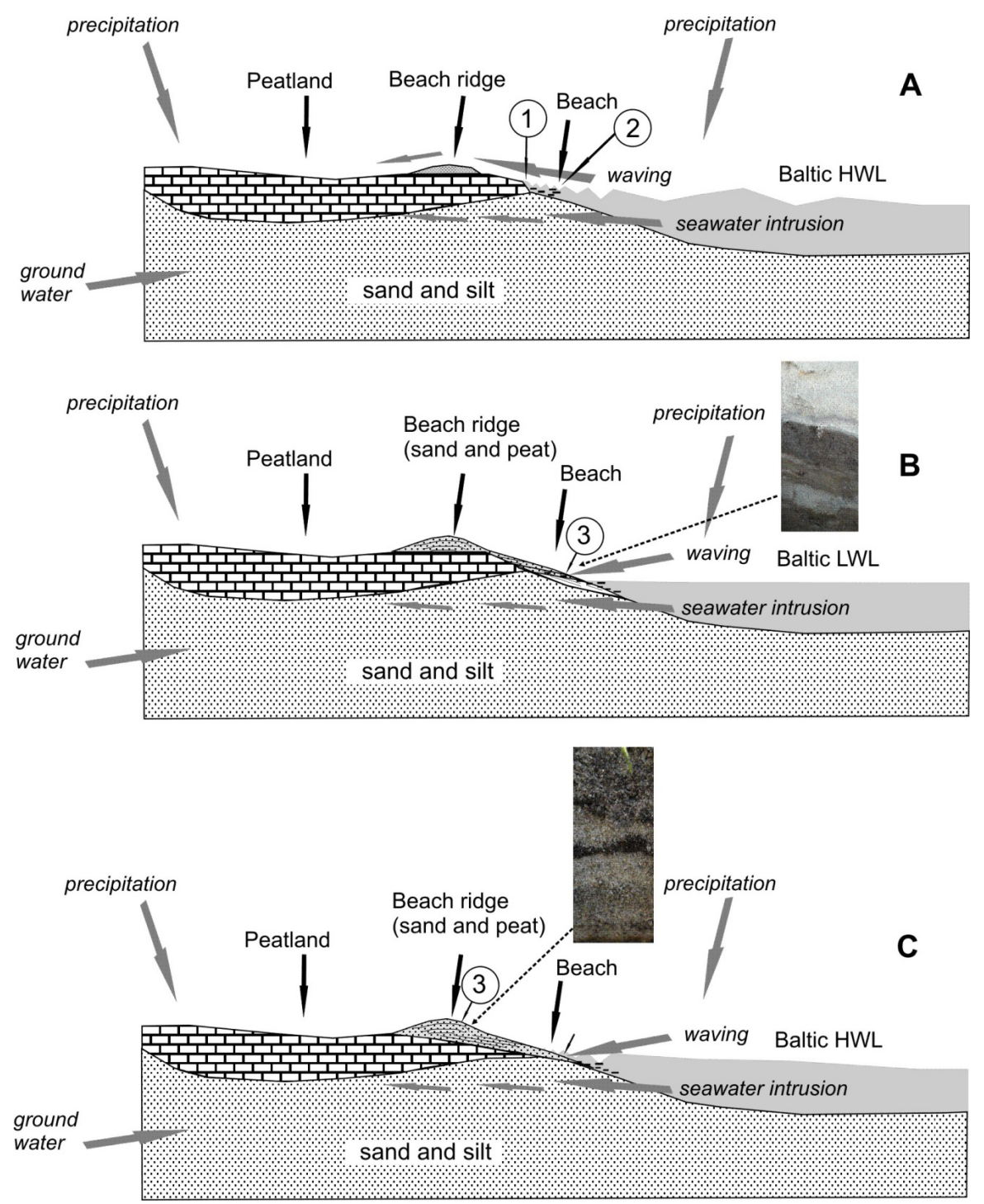

Figure 7. Pattern of brackish marsh soil formation with the allochthonous organic matter in the Beka Reserve. A - abrasion of the coastal peatland, B - during low water level (LWL) periods, $\mathrm{C}$ - during high water level (HWL) periods. Explanations: 1 - zone of the peat abrasion, 2 -washed out fragments of peat, 3 - allochthonous peat

rial was disturbed. This fact constituted a further confirmation of the allochthonous origin of organic matter accumulated in the studied brackish marsh soils. It should be noted, however, that peat deposits washed away by seawater were not the only source of soil organic matter. Some macroremains (mainly of ruderal plants and trees) could have also arrived from the nearby regions (e.g. the former village of Beka) as a result of stormwater flows over the land, which then retreated after being enriched with organic matter.

\section{Conclusions}

The analysed soils were characterised by specific properties resulting from a constant inflow of allochthonous organic matter derived from the washed-out peat deposits. Despite similar morphological characteristics, they might have developed in slightly different environmental conditions, determined mainly by the Baltic water levels and morphology of the coast.

The negative impact of seawater on peat deposits was reflected in changes of organic matter chemical properties. The ${ }^{13} \mathrm{C}$ NMR spectral analysis revealed their increased 
aliphatic character caused by the ongoing decomposition process.

The organic matter of the studied soils was dominated by remains of plants typical of the peat bog-rush zone. In the uppermost (roof) horizons and layers, also species representing other habitats were present (e.g. ruderal plants, trees). This great heterogeneity of sedimentary environments within the soil profile, often without any direct relationship with places of research, confirmed the allochthonous origin of organic matter accumulated in the studied brackish marsh soils.

\section{Acknowledgements}

This study was financed by the Polish Ministry of Science and Higher Education (grant N305 231135, 2008-2011). The authors wish to thank Professor Renata Bednarek, Head of the Department of Soil Science, Nicolaus Copernicus University, Torun (Poland) for stimulating discussions on this work.

\section{References}

Beyer L., Cordsen E., Blume H.-P., Schleuss U., Vogt B. \& Wu Q., 1996, Soil organic matter composition in urbic anthrosols in the city of Kiel, NW-Germany, as revealed by wet chemistry and CPMAS 13C-NMR spectroscopy of whole soil samples, Soil Technology 9: 121-132.

Błaszkowska B., Gerstmannowa E. \& Narwojsz A., 1996, Środowisko fizyczno-geograficzne [Physical and geographical environment], [in:] Z. Lenartowicz (ed.), Monografia rezerwatu przyrody Beka [Monography of the Beka Reserve], Materiały do monografii przyrodniczej regionu gdańskiego, Wyd. Gdańskie, Gdańsk: 88-99.

Cyberski J. \& Szefler K., 1993, Klimat Zatoki i jej zlewiska [Climate of the Bay and its catchment], [in:] K. Korzeniewski (ed.), Zatoka Pucka [Puck Bay], Instytut Oceanografii UG, Gdańsk: 14-39.

Drzymulska D., 2003, Znaczenie analizy subfosylnych makroszczątków roślinnych i stopnia rozkładu torfu dla rekonstrukcji paleośrodowiskowych [The importance of subfossil plant remnants and peat decomposition degree analyses for palaeoenvironment reconstruction], Kosmos 52 (2-3): 299-306.

Frey D. G., 1964, Remains of animals in quaternary lake and bog sediments and their interpretation, Archiv für Hydrobiologie 2: 1-114.

Guidelines for Soil Description, 2006, Food and Agriculture Organization of the United Nations, Rome.
Hulisz P., 2007, Wybrane aspekty badań gleb zasolonych w Polsce [Selected aspects of salt-affected soil research in Poland], SOP, Torun.

Hulisz P., 2011, Genesis, properties and systematic position of alluvial soils developed from sandy marine sediments (Beka, Gulf of Puck), [in:] M. Drewnik, A. Kacprzak, W. Szymański (eds.), Historia i kierunki rozwoju geografii gleb w Polsce, UJ Kraków: 69.

IUSS Working Group WRB, 2007, World Reference Base for Soil Resources 2006, first update 2007, World Soil Resources Reports 103, FAO, Rome.

Jankowska H. \& Łęczyński L., 1993, Charakterystyka brzegów zatoki na tle budowy geologicznej [Characteristics of shores of the bay on the background of the geological structure], [in:] Zatoka Pucka [Puck Bay], K. Korzeniewski (ed.), Instytut Oceanografii UG, Gdańsk: 303-308.

Jokiel J. \& Woźniak E., 2012, Czasowe zmiany sytuacji hydrograficznej słonych obszarów podmokłych rezerwatu Beka [Temporal changes in the hydrographic situation in salt marshes of the Beka nature reserve], Inżynieria Ekologiczna 29: 57-65.

Kögel-Knabner J., 1997, ${ }^{13} \mathrm{C}$ and ${ }^{15} \mathrm{~N}$ NMR spectroscopy as a tool in soil organic matter research, Geoderma 80 : 243-270.

Kornaś J., 1977, Analiza flor synantropijnych [Analysis of synanthropic flora], Wiad. Bot. 21: 85-91.

Kowalewski G., 2007, Analiza makroszczątkowa w badaniach paleolimnologicznych [Plant macroremain analysis in the palaeolimnological studiem], Studia Limnologica et Telmatica 1(1): 67-82.

Kramarska R., Uścinowicz S. \& Zachowicz J., 1995, Origin and evolution of the Puck Lagoon, [in:] K. Rotnicki (ed.), Polish Coast: Past, Present and Future, Journal of Coastal Research, Special Issue: 187-191.

Nowacki J., 1993, Termika, zasolenie i gęstość wody [Thermals, salinity and density of water], [in:] K. Korzeniewski (ed.), Zatoka Pucka [Puck Bay], Instytut Oceanografii UG, Gdańsk: 79-111.

Podbielkowski Z. \& Tomaszewicz H., 1996, Zarys hydrobotaniki [Outline of the hydrobotanics], PWN, Warszawa.

Pracz J., 1989, Właściwości gleb tworzących się przy udziale słonej wody gruntowej w polskiej strefie przybałtyckiej [Properties of soils formed under the influence of saline ground water in the region of the Polish Balic coast], Rozprawy naukowe i monografie, Wyd. SGGW-AR, Warszawa.

Pracz J. \& Kwasowski W., 2005, Organiczne gleby słone występujące w rejonie Zatoki Puckiej [Organic saline soils from the area of the Puck Bay], Roczniki Gleboznawcze 46 (3/4): 89-99.

Santín C., González-Pérez M., Otero X. L., Vidal-Torrado P., Macías F. \& Álvarez M. Á., 2008, Characterization 
of humic substances in salt marsh soils under sea rush (Juncus maritimus), Estuarine Coastal and Shelf Science 79(3): 541-548.

Strzelecka J. \& Gonet S. S., 2009, Effect of gamma irradiation on properties of soil humic acids, Polish Journal of Soil Science 42(2): 203-210.

Stuermer D. H. \& Payne J. R., 1976, Investigation of seawater and terrestrial humic substances with carbon-13 and proton nuclear magnetic resonance, Geochimica et Cosmochimica Acta 40: 1109-1114.

Systematics of Polish Soils, $5^{\text {th }}$ edition [Systematyka Gleb Polski, Wydanie V], 2011, Marcinek J. \& Komisarek J. (eds.), Roczniki Gleboznawcze 62 (3).

Urbański J. A. \& Ślimak A., 2008, Assessing flood risk and detecting changes of salt water inflow in a coastal micro-tidal brackish marsh using GIS, Oceanological and Hydrobiological Studies 37(3): 3-20.

Uścinowicz S., 2006, A relative sea-level curve for the Polish Southern Baltic Sea, Quaternary International 145-146: 86-105.

Velichkevich F. Y. \& Zastawniak E., 2006, Atlas of the Pleistocene vascular plant macrofossil of Central and Eastern Europe, Part 1 - Pteridopytes and monocotyledons, Kraków.

Wszałek-Rożek K. \& Markowski R., 2010, Zróżnicowanie florystyczne zachodniego obrzeża Zatoki Puckiej (Północna Polska) [Floristic diversity of the west coast of Zatoka Pucka (northern Poland)], Acta Botanica Cassubica 7-9: 55-78. 
